Shenderuk O. B.,

Candidate of Pedagogical Sciences, Assistant Professor at the Department of Foreign Languages, Academy of the State Penitentiary Service, Chernihiv, Ukraine

\title{
THE AUDIO-LINGUAL METHOD AS A SECOND-LANGUAGE TEACHING APPROACH
}

The article is an attempt to solve the problem of teaching foreign languages with the help of audio-lingual method that is outbreak of the World War II. We study languages by means of various methods, techniques and approaches. Their using increases the chances of learning taking place. Proper use of different methods and approaches in English classes is a vital part of achieving fluency and mastery of a language. Methods prescribe what materials and activities should be used, how they should be used and the role of the teacher in this process. The task of a teacher is to create the conditions for practical language learning for each student, to choose such method of teaching that would enable every student to show his ability, creativity and increase his cognitive activity in foreign languages. Nowadays there are many types of learning and teaching activities of foreign languages among which the audio-lingual method. The article deals with the concept of audio-lingual method, its general and specific objectives, learner and teacher's roles. It reveals advantages and disadvantages and different points of view on the issue of audio-lingual method. Among the basic pros we can elucidate natural order of skills presentation such as: listening, speaking, reading and writing. As for the corns, the serious one is there is no challenge for learners. The main characteristics of the mentioned method are specified and reported. There is little or no grammatical explanation. Great importance is attached to pronunciation. There is dependency on mimicry, memorization of set phrases, and overlearning. It heightens the need to become orally proficient. It is influenced by structuralism and behaviorism.

Key words: audio-lingual method, principles, peculiarities, advantages and disadvantages, teaching foreign languages.

Formulation of the problem. Methods play a significant role in determining the outcomes of educational endeavors. There are three main facts that influence the process of studying. These are: students, course and teaching strategies [1, p. 112]. Each of these elements has an impact on students' approach to learning. So, the problem of teaching methods is rather complex and complicated. On the one hand, it is widely described by the scientists, but on the other hand, there are some peculiarities of using this or that method while teaching or learning a foreign language. Accordingly, the problem of audio-lingual method is rather actual and important. 
Analysis of the latest research. Researchers have demonstrated interest in students' learning methods, how they learn and why they chose a particular method for learning. According to A. Ahmad, learning can be defined as the process of acquisition of knowledge [1, p. 115].

A. Yuliana studied the effectiveness of audio-lingual method as an alternative method in improving the students' speaking. According to her we have to use drills if we want the students to be able to speak English communicatively. Furthermore, she explains that drills, as part of audio-lingual method, have been used in teaching speaking. As the primary goal of the audio-lingual method is to use the target language communicatively, drills are suitable for teaching speaking. She concluded that the students' achievement in speaking skills by using audio-lingual teaching as the alternative method had a significant improvement. Among the advantages she points out a students' great enthusiasm during the lesson. Students become more confident and motivated in learning the language because of the teaching aids and materials used in the class along with the provision at the teacher's positive reinforcement. With the positive reinforcement, as she mentioned, students' intrinsic motivation became promoted that was the most fundamental to learn the language for their own self-perceived needs and goals leading them to positive attitudes towards the teacher, the class, the teaching method and language learning. After A. Yuliana, audio-lingual method as an alternative method of the teaching process is a good way to be applied in the first year students of senior high school to improve their ability in speaking. To her mind, the teacher should give more chances to the students to be more active, and let the students to do several practices. He/she should trust the students that they are able to do those activities by themselves. The teacher only observes and helps the students when they meet difficulties. High appreciation from the students does not make the teachers in a hurry to add more words, sentences or dialogues to learn. The teacher should not rush to add new material before their students internalize the words, sentences, and or dialogues given before.

According to P. Vitthal there are some trends which are prevalent in English language teaching. These are:

1. Networking, interest and support groups. 
2. Learner centeredness and learners needs.

3. Reflective practice and teachers learning.

4. Portfolio development for teachers.

5. Syllables design/materials development.

6. Criticism of published materials.

7. English as an International language.

8. Corpora [7].

The aim of the article is to analyze the information concerning audio-lingual method, to point out its peculiarities, advantages and disadvantages to use it adequately.

The main material. This method is based on the principles of behavior psychology and adapted many of the principles and procedures of the Direct Method, in part as a reaction to the lack of speaking skills of the Reading Approach. It was widely used in the 1950s and 1960s, and the emphasis was not on the understanding of words, but rather on the acquisition of structures and patterns in common everyday dialogue. The audio-lingual method had its origins during World War II when it became known as the Army Method. It is also called the Aural oral approach. It is based on the structural view of language and the behaviorist theory of language learning. Its patterns are elicited, repeated and tested until the responses given by the student in the foreign language are automatic.

The audio-lingual method is still in use today, though normally as a part of individual lessons rather than as the foundation of the course. These types of lessons can be popular as they are relatively simple, from the teacher's point of view, and the learner always knows what to expect. Some of the most famous supporters of this method were Giorgio Shenker, who promoted guided self learning with the Shenker method in Italy, and Robin Callan, who created the Callan method [6].

The Audio-lingual Approach to language teaching has a lot of similarities with the Direct Method. Both were considered as a reaction against the shortcomings of the Grammar Translation method, both reject the use of the mother tongue and both stress that speaking and listening competences preceded reading and writing competences. But there are also some differences. The direct method highlighted the teaching of vocabulary while the audio-lingual 
approach focus on grammar drills. New material is presented in the form of a dialogue. Based on the principle that language learning is a habit formation, the method fosters dependence on mimicry, memorization of set phrases and over-learning. Structures are sequenced and taught one at time. Structural patterns are taught using repetitive drills. Little or no grammatical explanations are provided, grammar is taught inductively. Skills are sequenced: listening, speaking, reading and writing are developed in order. Vocabulary is strictly limited and learned in context. Teaching points are determined by contrastive analysis between learners. There is abundant use of language laboratories, tapes and visual aids. There is an extended pre-reading period at the beginning of the course. Great importance is given to a precise native-like pronunciation. The use of the mother tongue by the teacher is permitted, but discouraged among and by the students. Successful responses are reinforced; great care is taken to prevent learner's errors. There is a tendency to focus on manipulation of the target language and to disregard content and meaning. This approach focused on examining how the elements of language related to each other in the present, that is, "synchronically" rather than "diachronically".

Here are some characteristics of the audio-lingual method:

- language learning is habit-formation;

- mistakes are bad and should be avoided, as they are considered bad habits;

- language skills are learned more effectively if they are presented orally first, then in written form;

- analogy is a better foundation for language learning than analysis;

- the meanings of words can be learned only in a linguistic and cultural context;

- drills are used to teach structural patterns;

- set phrases are memorized with a focus on intonation;

- grammatical explanations are kept to a minimum;

- vocabulary is taught in context;

- audio-visual aids are used;

- focus is on pronunciation;

- correct responses are positively reinforced immediately $[3 ; 5 ; 6]$. 
The main activities include reading aloud dialogues, repetitions of model sentences, and drilling. Key structures from the dialogue serve as the basis for pattern drills of different kinds. Lessons in the classroom focus on the correct imitation of the teacher by the students. Not only are the students expected to produce the correct output, but attention is also paid to correct pronunciation. Although correct grammar is expected in usage, no explicit grammatical instruction is given. It is taught inductively. Furthermore, the target language is the only language to be used in the classroom (Table).

Table

Audio-lingual method main characteristics [3, p.10]

\begin{tabular}{|l|l|}
\hline Main skills focus & $\begin{array}{l}\text { speaking and listening, grammatically correct } \\
\text { sentences }\end{array}$ \\
\hline Typical forms of interaction & T-St, T-Cl, St-St, Ind (tape recorder) \\
\hline Typical exercise types & $\begin{array}{l}\text { drills, substitution tables, imitation, transformation, } \\
\text { sound discrimination, memorization of dialogues }\end{array}$ \\
\hline Role of teacher & prove of stimuli and reinforcement, drill-master \\
\hline Attitude to error & $\begin{array}{l}\text { all attempts to avoid mistakes (students may learn } \\
\text { their mistakes and form wrong linguistic habits) }\end{array}$ \\
\hline $\begin{array}{l}\text { Attitude to use of mother } \\
\text { tongue }\end{array}$ & $\begin{array}{l}\text { use of mother tongue avoided at the lesson but } \\
\text { possible difficulties predicted through comparative } \\
\text { analysis }\end{array}$ \\
\hline
\end{tabular}

According to our observation there are some hints for using audio-lingual method in teaching English:

1. The teacher should be careful to insure that all of the utterances that students will make are actually within the practiced pattern. For example, the use of the auxiliary verb have should not suddenly switch to have as a main verb.

2. Drills should be conducted as rapidly as possible so as to establish a system.

3. Ignore all but gross pronunciation errors when drilling for grammar practice.

4. Use shortcuts to keep the pace of drills at a maximum. Use hand motions, signal cards, notes etc to cue a response. You are a choir director.

5. Use normal English stress, intonation and juncture patterns conscientiously. 
6. Drill material should always be meaningful. If the content words are not known, teach their meanings.

7. Intersperse short periods of drill (10 minutes) with very brief alternative activities to avoid fatigue and boredom.

8. Introduce the drill in this way:

a) focus (by writing on the board, for example) establish a system;

b) exemplify (by speaking model sentences);

c) explain (if a simple grammatical explanation is necessary);

d) drill.

9. Don't stand in one place, move about the room standing next to as many different students as possible to check their production. Thus you will know who to give more practice to during individual drilling.

10. Use the backward buildup technique for long and/or difficult patterns.

Sample:

- tomorrow;

- in the tomorrow;

- will be eating in the tomorrow.

11. Arrange to present drills in the order of increasing complexity of student's response. The question is: «How much internal organization or decision making must the student do in order to make a response in this drill»? Thus: imitation first, single-slot substitution next, free response last.

The analysis of scientific papers gave us opportunity to determine advantages of audio-lingual method:

- It aims at developing listening and speaking skills which is a step away from the Grammar-translation method.

- The use of visual aids has proven its effectiveness in vocabulary teaching.

- Authentic materials.

- Language items presented in dialogues, not in isolation. writing.

- Natural order of skills presentation: listening, speaking, reading,

- Students could often see immediate results [3, p. 12].

Disadvantages of audio-lingual method: 
- The method is based on false assumptions about language. The study of language does not amount to studying the "parole", the observable data.

- Mastering a language relies on acquiring the rules underlying language performance. That is, the linguistic, sociolinguistic, and discourse competences.

- The drills are meaningless, no communication.

- Repetition is boring.

- Practice for the sake of practicing [3, p. 11].

- Meaning is often irrelevant.

- Lack of flexibility.

- Overestimated role of drilling.

- No challenge for learners.

- Misinterpretation due to lack of explicit grammar rules [3, p. 12].

- The method's insistence on repetition and memorization of standard phrases ignored the role of context and knowledge in language learning.

During the last decade many innovations happened. Teachers who practiced Grammar-Translation method during the previous year solely relied on blackboard as the apt tool to impact communication skills and the nuances of English. Later on, over head projectors dominated classroom. Such teachers believed in the dictum of drills and practice. In the later years of 1970's audio-lingual method fell into disregard.

Conclusions. This study investigated the preference of using audio-lingual method among different learning methods. It suggests that this method is a useful one, though it has certain disadvantages. There had been too many methodologies of teaching English. One method is embraced as a development of the other. No method has been a panacea for the solution of the English Language Teaching problems. Nowadays the ere of method is over and the ELT as of the current scenario is in "post method thinking" [7, p. 42]. It is possible for everyone to learn English in the most enjoyable manner if it is supplied with the right kind of materials and pedagogy produced by one's own native wisdom. The success of the implementation of this method, to my mind, as any other one, depends on the model of a 
teacher. He should be a lifelong learner, a good example for his students.

\section{References}

1. Ahmed, A. \& Ahmad, N. (2017), "Comparative analysis of rote learning on high and low achievers in graduate and undergraduate programs", Journal of Education and Educational Development, Vol. 4 (1), pp. $111-129$.

2. Brown, H. (2000), Principles of language learning and teaching, (4th ed.), Longman, New York.

3. One-month in-service training course for English language teachers. Workbook (Pilot version) (1999), The British Council Ukraine and the Ministry of Education of Ukraine, Kyiv, 15 June 1999, 264 p.

4. Reddy, S. (2012), "Importance of English and different methods of teaching English", Journal of Business Management and Social Sciences Research (JBM\&SSR), Vol. 1 (3), pp. 25-28, available at: https://borjournals.com/a/index.php/jbmssr/article/view/145/1197 (accessed 7 December 2018).

5. Richards, J. C. \& Rogers, T. S. (1986), Approaches and methods in language teaching: A description and analysis, Cambridge University Press, Cambridge, UK.

6. Taylor, A. (2014), "Language teaching methods: overview", available at: https://blog.tjtaylor.net/author-alex-taylor/ (accessed 11 December 2018).

7. Vitthal, P. "Innovative techniques, methods and trends in English Language Teaching", Journal of Humanities and Social Science, Vol. 20(6), pp. 40-44, available at: https://iosrjournals.org/ (accessed 20 November 2018).

8. Yuliana, A. (2013), "The application of audiolingual method to improve student's speaking ability in SMA PGRI 1 SIDOARJO", Journal Pendidikan Bahasa Iggris STKIP PGRI Sidoarjo, Vol. 1 (1), pp. 88-93.

\section{Шендерук О. Б.,}

кандидат педагогічних наук, доцент кафедри іноземних мов,

Академія Державної пенітенціарної служби, м. Чернігів, Україна АУДІОМОВНИЙ МЕТОД ЯК НАВЧАЛЬНИЙ ПІДХІД ДО ВИВЧЕННЯ ДРУГОЇ МОВИ

У статті окреслено проблему викладання іноземних мов за допомогою аудіомовного методу. На сьогодні існує багато різних методик, підходів та методів викладання іноземних мов, серед яких аудіомовний або аудіолінгвальний метод, створений Чарльзом Фрізом. У статті розглянуто аудіомовний метод, представлено його загальні та специфічні риси, показано роль учня та педаго- 
га у прочесі навчання за допомогою иъього методу. Визначено основні характеристики зазначеного методу, його переваги та недоліки, а також різні точки зору шцодо його застосування. До основних переваг аудіомовного методу віднесено забезпечення всіх видів мовленнєвої діяльності: аудіювання, говоріння, читання та письмо, які відіграють ключову роль у процесі мовлення. До основних недоліків віднесено відсутність мотиващії до застосування методу з боку учнів.

Ключові слова: аудіомовний метод, аудіолінгвальний метод, підходи, особливості, переваги та недоліки, викладання іноземних мов. 